$J J M L L$

\title{
Language and Politics: Prose as a Medium of Societal Apartheid in Shakespeare's Julius Caesar
}

\author{
Mufeed Al-abdullah* \\ Department of English, Jerash University, Jordan
}

Received on: 19-1-2020

Accepted on: 14-6-2020

\begin{abstract}
This paper studies the use of prose in Julius Caesar as a tool of political and social apartheid and class discrimination. Usually, Shakespeare assigns blank verse to upper-class characters and prose to lower class ones. The study analyzes three occasions in which prose is used by two patricians and an eloquent cobbler. The paper means to explain the diversion of patricians to prose and add another voice to the already heaping interpretations given in criticism. It argues that the diversion of the two patricians to prose has two functions. Firstly, it shows that prose is indigenous to the poor and the patricians use it when they address the poor or talk about them. Secondly, Shakespeare shows that the diversion of the patricians to prose is a wrong choice and leads to moral depravity or failure of mission. In contrast, the cobbler uses prose effectively because it is indigenous to him and he feels at home using it. The study uses the contextual approach to analyze the three speeches.
\end{abstract}

Keywords: Prose, Blank Verse, Patricians, Plebeians, Aristotelian Rhetoric, Republican Politics.

\section{Introduction}

Shakespeare's use of prose and blank verse in his plays is not merely an aesthetic or artistic choice. These modes of expression are really significant and technically meaningful. Shakespeare's Elizabethan and Jacobean plays are poetic dramas that use blank verse which became a fashionable dramatic medium in England in the sixteenth century (Parini 2005, 655). Nevertheless, Shakespeare uses prose also throughout his canon, especially in the comedies and comic scenes in the history plays (Ballard, 2016; and Vickers 1968). Vickers (1968) explains that the Elizabethans viewed prose as inferior to verse as a method of expression in literature. And since comedy involves characters "worse than the average," according to Aristotle's Poetics, a book that was widely celebrated and adhered to by Renaissance writers, it is thus natural that comedies include a considerable amount of prose allotted to the comic, thus "ridiculous" characters and themes.

Prose and verse are remarkably used in the exchanges of the patricians and populace in Julius Caesar. These two social groups compose an avidly stratified community of the play. The play also shows social cleavage between the two social orders. Besides, it demonstrates that the patricians are

\footnotetext{
๑ 2021 JJMLL Publishers/Yarmouk University. All Rights Reserved,

${ }^{*}$ Doi: https://doi.org/10.47012/jjmll.13.1.4

* Corresponding author: mufeedh2014@gmail.com
} 
Al-abdullah

engaged in the rivalry among themselves. Allan Bloom (1964) contends that in Julius Caesar and Coriolanus, Shakespeare presents Rome as two cities: "the city of the rich and the city of the poor" (1964, 79). He argues that the two cities form a coalition with no supreme value to bind them together. However, they are interdependent despite their opposition to one another. Bloom further explains that each of them "moderates the goals of the other by sheer force" $(1964,80)$. Nevertheless, the action of the play indicates that Shakespeare is biased for the elites and perceives "the city of the rich" as the sphere of all that is worthy and admirable; it is the city of the senators and heroes (Bloom 1964, 80). The playwright believes in the dynamic energy and supreme virtues of the distinguished few who can build a civilization and make progress, and, thus, he favors the rights and dominance of aristocracy and the "senatorial class" (Bloom 1964, 80). Among the aristocrats, there is always the possibility for individual achievement of wonders. In Julius Caesar, "Roman history is not the history of huge, impersonal movements, but that of great individuals," asserts Bloom $(1964,80)$. The values of heroism and championship are shown to be aristocratically exclusive. In contrast, the Elizabethan playwright presents the poor majority of the nation as mobs with limited insight, intuitive at best, in public affairs. They are fickle masses driven by their physical needs and can be easily gulled by any smart manipulator. Indeed, they are shown to be inhabited by fear and are easy to be enslaved and exploited by the mockery of the brilliant Machiavellian elites (Bloom 1964, 83). Similarly, Spotswood (2000) explains that the multitudes in Julius Caesar and Coriolanus are disarmed of individuality and shown as fragments to the singularity of patricians (Coriolanus: 1. 1. 221). He points out that the masses in Shakespeare's political plays "serve to reflect and enlarge the figure of the elite" (62). Even the cobbler, who temporarily distinguishes himself from the crowd in the opening scene, disappears among the crowd in the later scenes and loses his identity.

However, one can raise issues with these sharp judgments of Bloom and Spotswood, which can be moderated in light of the action of Julius Caesar. Shakespeare devotes the first three acts of the play to rhetorical and verbal confrontation and the last two acts to military combats. The verbal confrontation raises the conflict among the elites to the decisive point of assassinating Caesar. The plebeians, albeit the limited space allotted to them and the fickleness attributed to them, contrary to their counterparts in the source, posit a force to be taken into account whenever the patricians set their plans and proceed in action against or with Caesar (Bloom 1964, 80). Caesar himself depends on their support in his endeavors to topple the republican political system.

The two factions of society in the play are further segregated linguistically by the method of expression allotted to each in the play. Shakespeare's 'linguistic apartheid' is marked by assigning the fashionable blank verse to the aristocrats, whereas the less attractive inferior prose is assigned to the plebeians. Like in other plays of Shakespeare, prose is presented in Julius Caesar as a feature of the masses' domain. And as the masses provide a weighted force in the struggle between Caesar and most patricians, some of the patricians divert from using the medium of blank verse to that of prose in their endeavor to persuade the plebeians of a certain issue or when they talk about plebeian affairs. These ideas are available in research. However, this study intends to advance another vantage from which to analyze the uses of prose in Julius Caesar and to add another voice to the already heaping interpretations of the 
Language and politics: Prose as a Medium of Societal

Apartheid in Shakespeare's Julius Caesar

form of expression the social orders employ in their utterances. In Julius Caesar, in particular, the form of utterance indicates social positioning and purports political prejudice. As thus, verse, which is solely employed by the aristocrats, indicates elitism and power, whereas, prose points to social depravity and deterioration. Furthermore, the study hopes to show that when two aristocrats divert for once to the use of prose they disastrously fail to achieve their purpose of that diversion.

Remarkably, prose is scarcely used in Julius Caesar. It is used in Act I, Scenes 1 \& 2, and Act III, Scenes $2 \& 3$, scenes in which the plebeians are involved in the action of the play. The cobbler, Casca, and Brutus are given the biggest share of prose utterance, with the cobbler as the only plebeian among the three. This study analyzes their prose utterances or speeches in light of the thesis that prose is the domain of the low classes. When the patricians decline to prose, they use it either to talk about the mobs, as in the case of Casca, or address them, as in the speech of Brutus. It also means to demonstrate that the prose used by the elites to address the multitudes is a wrong choice and a digression from the expected norm. It is either used to ridicule the plebeians or show the supremacy of language and education by talking over their heads.

Notably, tragic characters at times speak in prose, a practice that makes a distraction from the norm of expression allocated to their class. Vickers (1968) explicates that upper-class characters resort to prose in abnormal situations. For instance, when they decline in reason (e.g., Othello under the fits of jealousy), suffer psychological disturbances (e.g., Lady Macbeth in her somnambulistic state), become mad (e.g., Ophelia after the death of her father), or pretend madness (e.g., Hamlet). This study adds two more reasons for noble characters to switch to prose, namely when they address the lower classes or talk about their affairs or activities. The study also proposes that whenever aristocrats decline to prose, as Shakespeare's practice purports, they fail to realize their goals or deteriorate linguistically and degenerate morally.

\section{Review of literature}

Using prose and/or verse in Shakespeare's dramas has provoked numerous, at times, controversial studies. One of the most notable studies, which this study draws on, is Brian Vickers' (1968, reprint. 2005) erudite and indispensable book, The Artistry of Shakespeare's prose, which surveys and analyzes the prose in Shakespeare's canon from an artistic perspective. His critical approach includes the study of imagery, linguistic structures, and rhetorical structures of the prose in the canon (19-51). In his survey, he recognizes an increase in the amount of prose from the early histories and comedies of Shakespeare reaching a peak in the Merry Wives of Windsor, which is about $90 \%$ a prose play. He points out that some plays of Shakespeare have almost equal amounts of prose and poetry like Much about Nothing, As You Like It, and Twelfth Night. Other Elizabethan plays, like Love's Labour's Lost, have a considerable share of prose (Vickers 1968, 4). This was natural in the evolution of Shakespeare's career in the Elizabethan era which started with comedies and history plays before writing the tragedies of Julius Caesar and Hamlet, and before opening the Globe Theater in 1599. Since then prose started to recede in volume, but not in value, concludes Vickers $(1968,4)$. Furthermore, he claims that Shakespeare's prose in the great 
Al-abdullah

tragedies is his best achievement $(1968,4)$. Whether we agree with this evaluation or not, it is sure that prose is used in the Jacobean plays (1603-1611) on a low, but very significant, scale.

Similarly, Kim Ballard contends that Shakespeare's use of prose and verse as forms of composition belongs partly to the literary traditions of the Elizabethan age. However, she argues that Shakespeare utilizes these forms for dramatic and pragmatic reasons, such as portraying psychologically oriented characters, mapping relationships, enhancing the plot, and exploring thoughts and attitudes (Ballard 2016). She further argues that prose at the time of Shakespeare was considered suitable for comic scenes and characters of low social rank and verse for tragic scenes and characters of high social rank. Like Vickers, Ballard (2016), notices Shakespeare's deviation from this norm in his early career. She further argues that mixing prose and verse started to appear in drama towards the end of the sixteenth century. She gives an example from The Taming of the Shrew (1593-94), in which Katherina and Petruchio generally use blank verse during the process of courtship. However, when Katherina is tamed and they are happily married, they shift to prose as a sign of relaxation, according to Ballard (2016). Of the instances when Shakespeare departs from the norm of assigning verse to upper-class characters are the cases of Titus when he uses prose in an exchange with the clown in Act 4, Scene 3, and the prose exchanges of Benedick and Beatrice in Much Ado About Nothing. Ballard (2016) also gives the example of Henry V who has an exchange in prose with two soldiers before the Battle of Agincourt, and in the scene where he courts Catherine. In Hamlet, Ballard argues that the prose assigned to Hamlet after the visitation of the Ghost is meant to show the complexity of his psychology after the story of the murder of his father and the hasty remarriage of his mother to his uncle. Ballard (2016) explains that in these cases Shakespeare wants to point out the multidimensionality of characters rather than their stereotypical nature.

Other critics like Visser (1994) come down heavily on the prejudiced Shakespearean practice of presenting the masses, a practice that converges with the deeply rooted tradition that views commoners from above. He holds that Shakespeare's view of political crowds belongs to the mainstream of political thinkers, beginning from the classical times onward to theorists like Taine, Carlyle, Arnold, and Gustave Le Bon, Freud, and other recent psychologists who perceive the political crowds from the "view from above" perspective. This stream of theorists has always written in the interest of governing classes that felt endangered by the aspirations of people who took part in "mass political movements" (Visser 1994, 23). He points out that only George Rude and similar social historians changed the perspective to a "view from below" (1994, 23), which introduced a major revision of the traditional stream. According to this view, Shakespeare's depiction of the political crowd is shown to be based on class prejudice.

Generally, Shakespeare was biased for the governing monarch and upper classes. That raises the question about his view of low classes and masses in general. Some critics endeavor to seek the roots of Shakespeare's biased view of the aristocrats and uncomplimentary attitude toward the low classes. Allan Bloom (1964) maintains that in Julius Caesar, Shakespeare reviews Roman history and aristocrats from the Elizabethan perspective (78). He argues that the Elizabethans admired and learned a lot from Roman literature, education, and law $(1964,78)$. Similarly, Rollins expounds that Shakespeare, in Julius Caesar, 
Language and politics: Prose as a Medium of Societal

Apartheid in Shakespeare's Julius Caesar

was one of Renaissance intellectuals that went back to classical legacy to search for parallels to contested contemporary political issues and civil disobedience. Lauren Leigh Rollins (2017) elucidates that "Shakespeare's anachronistic representation of tyranny and Roman republicanism... reveals Shakespeare's view of his own historical moment" (166). As a writer, Shakespeare celebrated the established monarchic political system and sided against the civil troubles that threatened the recognized order. In Julius Caesar, he renders changes on the role of the populace in the political system in Rome. In Plutarch, the commoners were against changing the republic into a monarchy despite their traditional support of Caesar. When they noticed Caesar's imperial interests at the time he was a consul, they started thinking of Brutus, an adamant defender of the republican system, as a replacement (Dryden 1864, 890). But when Caesar was killed, the commoners of Plutarch were apathetic to Brutus' speech (Dryden 1864, 893). That shows that the commons in Plutarch were not as fickle as their counterparts in Shakespeare.

Because of his discriminatory perception of the patricians and the plebeians, Shakespeare assigns the superior blank verse to the senatorial community and the inferior prose to the poor plebeians. And since Julius Caesar is mainly about the rivalry among the patricians, the playwright devotes $93 \%$ of the bulk of the play to blank verse (Vickers's chart 1968, 433) and only 7\% to prose, according to Vickers' table of the distribution of prose in the plays of Shakespeare $(1968,433)$. The researcher holds that the space allotted to one faction or another is relevant to the power dialectics in the play. The fact that the low classes are given very little space in the play indicates that they are given no power. However, the political system embraced by Shakespeare indicates emphatically that the senatorial rivals keep in mind the ability of the masses to turn the tables if not taken into account when political disputes are undertaken. Besides, the values of chivalry, heroism, knighthood, and military skills are shown to be limited to the elites and are, by no means, claimed by the plebeians. This is why the plebeians appear in the first three acts of the play during verbal combats and political maneuvers, but they recede to the background and play no role in Acts IV and V, the acts devoted to military confrontation which requires heroism and chivalry. In Julius Caesar, valor, magnitude, and leadership are of no concern to the masses, but are solely the concern of the governing patricians.

\section{Discussion}

The following discussion shows that in the stratified community of the play, the form of expression in prose or verse is deliberately utilized by Shakespeare, particularly in a drama that presents a tense society on the verge of a political massive change. The stratification of society is reinforced by the linguistic apartheid strictly observed in the play. The analysis scrutinizes the three major prose speeches arranged according to their occurrence in the play within the uptight political scene in Rome during the reign of Caesar.

\subsection{The cobbler's prose: combating with power}

The initial persistent alternation of blank verse and prose in the opening interlocution between the tribunes and the cobbler in Act 1 Scene 1 has significant indications as far as this study is concerned. 
Al-abdullah

Analyzing this initial scene offers a new scope that sheds light on Shakespeare's politics of prose. Some critics recognize the significance of this scene and interpret it from different perspectives. Lawrence Danson (2004), for instance, finds in the scene a miniature of the whole action of the play, especially its avid mood of confrontation and hostility among men overwhelmed with the dominant feeling of ambiguity in the whole of the play. That sense is anticipated by the tribunes' equivocation in the scene resulting from the cobbler's ambiguous prose answers about his vocation. Turgut (2015) takes another path and interprets the play in light of modern political theory of perception operation/management. He finds in this scene the beginning of the process of perception operation that sets out to reconstruct the cognition of the plebeians so that they question Caesar's political and institutional legitimacy (46). The tribunes blank verse endeavors to reprove the immorality of the plebeians' celebration of Caesar's triumph over the blood of Pompey, who was once their dear champion. Rollins (2017) finds in the scene an exposition of a deeply rooted hierarchical problem of social inequity. She argues that the consistent feature of Shakespeare's Roman "republicans" is that they are anything but republican. They are infected by what John Velz calls "unmistakable connotations of kingship" (Rollins 2017, 168). The tribunes who were elected by landowning members represented people who had no right to vote (Rollins 2017, 168). The tribunes in Scene 1 practice power over the plebeians while they have no real power similar to that of the patricians. Athanasios Boulukos (2004) considers the scene as the initial skirmish between the Caesarian forces and their opponents. He analyzes the ambiguity with which the cobbler confuses the tribunes, his philosophical punning, and the mysteriousness of the scene concerning its relation to the play.

This study adds another track for interpreting the scene. The researcher believes that the scene posits the method of expression (prose/verse) as a codified system of class stratification. The clash in the scene between the plebeians and their representatives over the plebeian switching alliance from Pompey to Caesar is expressed in distinctive forms of language delivery. Shakespeare gives a state of immediacy and emphasis to linguistic apartheid in which the interlocutors rhythmically and consistently alternate their parts of the exchange in verse and prose. The whole scene looks like a ping-pong game in which the cobbler combats the two tribunes. The tribunes are supposedly plebeians elected to represent Bloom's city of the poor $(1964,79)$. They gather power, but they are prohibited from social ascension (Rollins 2017 , 168; and Ginn 2019, 4).

Another significant indicator of power is the space or the volume allotted to the interlocutors. Notably, the share of the plebeians is 21 out of 75 lines (i.e. 28\%) of the utterance in the whole scene, in a play in which prose is allowed only $7 \%$ of the total utterance. Except for one sentence by the carpenter, the whole dialogue is mainly between the cobbler, on the one hand, and Marullus and Flavius, on the other. The mode and distribution of utterance convey artistic and political messages. Firstly, prose is the mode of utterance allotted to the low-class people. However, this is not the case in the whole canon of Shakespeare (Vickers 1968, 4), but it is completely true in this scene and, in Julius Caesar, as a whole. Secondly, the quantity of space given to the speakers, i.e. the space allowed to prose in the scene, reflects 
Language and politics: Prose as a Medium of Societal

Apartheid in Shakespeare's Julius Caesar

the distribution of power between the two parties. The strong party is given wider space in the parley congruous to its power in the scene as well as the whole play.

The tribunes present themselves as audacious adversaries of Caesar and pretend that they protect the people's interests against their will (Bloom 1964, 246). According to Miola (1985, 276), the tribunes' sense of authority stems from a moral stance against Caesar's parading to celebrate his victory over the sons of another prominent Roman leader, "Pompey's blood" (1. 1. 51). In contrast, the people in Plutarch's Lives did not receive that parade of Caesar well, and, thus, he organized a low profile celebration not to aggravate them (Dryden 1864, 886).

A short analysis of the linguistic confrontation at the outset of the play can lead to important conclusions pertinent to this study. Shakespeare in this scene reverses what is expected from the political and linguistic apartheid norms. The supposedly poor and politically suppressed cobbler surprises us by outshining his opponents with his rhetoric and language competence. In this scene, the cobbler, like other plebeians, maintains equivocal identity by his non-vocational dress (1.1.8) and by his exploitation of language. For instance, he manipulates the homophone of "sole" and "soul" in the uttered phrase of "a mender of bad soles" (1. 1. 14) in answer to Marullus' question about his trade. His cunning answer echoes the philosophical meaning of a reformer through the other end of the homophone "i.e., soul". And in retaliation to Flavius' irritated reproach, the cobbler requites it with an insult and a warning in a metaphor also based on the homophone: "Nay, I beseech you, sir, be not out with me; yet, / if you be out, sir, I can mend you" (1. 1. 16-7). The homophone dictates the metaphor in which Flavius is also compared to a sole that can be mended, especially with the awl, the cobbler's only tool of mending soles (1. 1. 21). Upon Marullus' inquiry about the meaning of the implied threat in the cobbler's words, the quick-witted cobbler, with an underlying current of humor, explains the word "mend" with the synonym "cobble" (1. 1. 19) from the jargon of his craft, which implies another menacing and threatening metaphor.

The attempt of Flavius to wrap up the dialogue gives the cobbler a chance to resume his dynamic metaphoric creativity and humor as he compares himself to a physician, the worn-out shoes to patients, and fixing shoes to the process of healing patients. Says the cobbler:

Truly, sir, all that I live by is with the awl: I meddle with no tradesman's matters, nor women's matters, but with $a w l$. I am, indeed, sir, a surgeon to old shoes; when they are in great danger, I recover them. (1. 1:21-23).

The cobbler multiplies his skillful wordplay with a cluster of puns: "sole," "all," and "withal," and "awl," (Boulukos 2004, 1085) which intensifies the ambiguity of his language. Boulukos (2004) explains that the deep philosophical meaning of the cobbler's paradoxes, images, metaphors, and puns echoes the paradox of the stoic Chrysippus which was popular in antiquity and is encountered in the works of Cicero and Horace, which were integral to Renaissance education (1083). In its fundamental form, it indicates that "the wise man achieves such virtue that he is at once king, rich man and a cobbler" (Boulukos 2004, 1083). Satire I.3, states Chrysippus' paradox: 
Al-abdullah

The wise man has never made himself shoes or sandals, but the wise man's still a cobbler... that smart fellow Alfenus, even after throwing all the tools of his trade away and shutting up shop, was still a cobbler; in the same way, the wise man alone is master of every craft, and hence a king (cited in Boulukos 2004, 1084).

This passage relates philosophy to cobblers: it suggests that shutting up the shop and putting the tools away does not change the identity of the cobbler. It shows the ignorance of Marullus and Flavius who superficially think that the cobbler's identity depends on his attire and open shop (Boulukos 2004, 1084). Whether Cicero and Horace were the direct sources of Shakespeare, it is difficult to prove. However, they provide an important aid to decode the parley of the cobbler and the Tribunes at the outset of the play (Boulukos 2004, 1084), and enable us to understand the deep thoughts behind the metaphors of the cobbler and the richness of his puns which give him the upper hand over the blank verse of his counterparts. The sharp cobbler is a predecessor of the gravedigger in Hamlet, with the exception that Flavius and Marullus cannot cope with his wit as does Hamlet with the gravedigger (Boulukos 2004, 1085). The figures of speech and paradoxes in the cobbler's language are not a feature of prose. However, the skill and mastery he demonstrates is a Shakespearean technique to show that the cobbler feels at home with prose as he maneuvers in his zone. This way, his language posits juxtaposition to Casca's crude language and Brutus' artificial show of classical rhetoric. The cobbler wins over the Tribunes with his indigenous eloquence, confuses them with his barrage of paradoxes, puns, and metaphors, and distinguishes himself with deeply rooted allusions to the rich traditions of culture.

In contrast, from the first sentence, even the first word Flavius utters: "Hence! Home, you idle creatures, get you home!" (1. 1. 1), the tribunes' tone is authoritarian, imperative, and infuriated. He dismisses the 'fickle' (Visser, 1994) crowding people and commands them to disperse from the streets and go home to lament their ingratitude to Pompey. Flavius' words forebode tension and conflicts that will dominate the action of the play hereafter.

The language of the tribunes, though molded in the fashionable modes of poetry, aggravates the interlocutor as well as the listeners with its repulsive aggressiveness. As the dialogue proceeds, the underlying current of an authoritarian utterance of the tribunes plunges sharply as incompetent and powerless as it fails to detect the identity of the equivocal cobbler, who is triply disguised under nonvocational attire, absence of a vocational label, and witty and puzzling prose.

To sum up, this scene creates an awareness of the confrontation and the dynamics of power from the very beginning of the play and simultaneously directs our attention to another form of confrontation in the play, namely that of the form of expression. Shakespeare takes us by surprise with this issue from the very outset of the play as the interlocutors exchange their utterances in two different forms of expression. The traditional assumption is that power correlates with verse as a form of expression and is simultaneously congruous to the volume of space allotted to the speaker. However, in this scene, the prose of the cobbler surpasses the verse of the dominant tribunes despite the scarcity of space allowed to him. He outshines them in cognition and implications of philosophy and confuses them with 
Language and politics: Prose as a Medium of Societal

Apartheid in Shakespeare's Julius Caesar

equivocations and rhetorical richness. The cobbler feels at home with this form of expression; it is his sphere in which he cannot be beaten even by people of authority.

\subsection{Casca's prose: plunging into vulgarity}

Notably, Casca's sole attempt on prose in Act 1 Scene 2 is an excursion outside his zone of blank verse. However, the excursion proves a disastrous moral decline and a reckless failure of expression. In Julius Caesar, Casca appears in the first three acts only. All the time he is given blank verse like the rest of the patricians and senators in the play, except the occasion on which he speaks in prose as he describes to Brutus the mob's reaction to Caesar's refusal of Antony's crown offers during the Lupercal celebrations. Remarkably, Brutus' and Cassius' questions to him are consistently in blank verse, whereas Casca's responses are in prose. Following this scene immediately, Casca, in a dialogue with Cicero in (1. 3 ) is given an ample room of 32 blank verse lines to elaborately describe the extraordinary turbulence of nature and the supernatural prodigies during that unprecedented stormy night. In the same scene, his dialogue with Cicero is followed by another with Cassius in which he is allotted 24 lines of verse. In that dialogue, Cassius derives Brutus' initial agreement to join the conspiracy against Caesar. The total space he is given in the two dialogues in Act 1, Scene 3 is 56 lines of blank verse. This is almost equal to Casca's prose in the preceding scene. In Act 2, Scene 1, Casca's role recedes to the background and is allotted less room with only 9 lines in a lengthy scene of 334 lines of poetry devoted to the conspiracy against Caesar. During the scene of the assassination in Act 3, Scene 1, his contribution recedes still further to 4 scattered lines of verse. After that scene, there is no mention of Casca till the end of the play. The total volume he is assigned in the play is 69 lines of blank verse and 54 lines of prose in the first 3 acts of the play with a total absence in the last two acts and with a steady decline in the space he is allotted from Act I to Act 3.

Casca's active presence is in the two successive scenes (1.2) and (1. 3), he uses prose in Scene 2 and an equal quantity of verse in Scene 3. His use of prose deserves some explanation which has not been adequately provided in scholarship on Shakespeare. Casca's prose in (1. 2), like Brutus' speech (3. 2), is an exception to this general norm of lingual stratification. But why does Shakespeare violate the norm of expression in Casca's case? This study assumes that the nature of the subject of Casca's prose keeps it in line with the tradition that when Aristocrats address the mobs or describe their affairs they decline to the use of prose. The subject of Casca is the mobs and how they react to Caesar's conduct. The gist of his report in prose to Brutus and Cassius is that Caesar manipulates the mobs (Yu 2007, 93). He reports that Antony offers him a crown which he declines three times and every time he rejects it, the multitudes shout aloud and applaud him. He describes their reaction as thus:

... the rabblement shouted, and clapp'd their chopt hands, and threw up their sweaty night-caps, and uttered such a deal of stinking breath because Caesar refused the crown, that it had almost choked Caesar, for he swooned and fell down at it: and for mine own part, I durst not laugh for fear of opening my lips and receiving the bad air. 
Al-abdullah

Marry, before he fell down, when he perceived the common herd was glad he refused the crown, he pluck'd me ope his doublet, and offered them his throat to cut: an I had been a man of any occupation, if I would not have taken him at a word, I would I might go to hell among the rogues:-and so he fell. When he came to himself again, he said, if he had done or said anything amiss, he desired their worships to think it was his infirmity. (1.2. 243-270, italics mine)

This narrative is loaded with the disdainful feelings toward the plebeians and contempt for the cunning Caesar and his royal ambitions (Yu 2007). He repeatedly insinuates that Caesar has not been serious about rejecting Antony's crown offers during the Lupercal revels, indicating that Caesar dissembles and acts upon the plebeians:

I saw Mark Antony offer him a crown; - yet 'twas not a crown neither, 'twas one of these coronets; - and, as I told you, he put it by once: but, for all that, to my thinking, he would fain have had it. Then he offered it to him again: then he put it by again: but, to my thinking, he was very loath to lay his fingers off it. And then he offered it the third time; he put it the third time by; and still, ... he refused it. (1. 2. 235-242, italics mine).

From these sentences, we notice that Casca belittles the coronet offered by Antony, and every time he reports Caesar's rejection of it, he adds his own opinion that Caesar wishes to keep it. Simultaneously, Casca overtly and callously annunciates his disgust and denigration of the mobs for their bestiality, dirtiness, reeking smell, and sweaty clothes along with their gullibility to the tricks of Caesar. His prejudiced and unfair account is reflected in the network of epithets he attributes to the plebeians. These offensive epithets include demeaning, odious terms, and animal metaphors. He refers to them with such terms as "rabblement," "the common herd," and "the rogues." These terms are hostile and dehumanizing as they deprive plebeians of their human entity and perceive them as a collective group of degenerate beings that serve as instruments for the realization of Caesar's royal ambitions (Al-Abdullah 2020). He further ridicules the plebeians for their "chopped hands", "sweaty caps", and "stinking breath" (1. 2. 240244). Worst of all is Casca's refrain from laughing at their foolery, as he brags, in order to avoid opening his mouth and inhaling their reeking breath. He inconsiderately testifies that Caesar himself has almost choked because of their stinking breath which has led to his fainting (1. 2. 245-246). Worst of all is his inhumane and sadistic report of Caesar's epilepsy: “[he] fell down in the market-place, and foam'd at mouth, and was speechless" (1. 2. 251-252). Casca further mocks Caesar for addressing the plebeians as "their worships" (1. 2. 269), considering this exaggerated phony reverence as a cunning and pragmatic mockery of Caesar, who intends to use the foolish commoners for the attainment of his political goals and transcendence above his patrician peers.

With regard to the commoners, Casca's speech is unjustified and atrocious. Besides, it contradicts itself. Their applauses of Caesar's rejection of the crown show that their political concern about maintaining the Republican political system is no less unwavering than the patricians'. They almost 
Language and politics: Prose as a Medium of Societal

Apartheid in Shakespeare's Julius Caesar

unanimously and recurrently applaud Caesar's rejection of Antony's offer of the crown. In reality, it is the senate that plans to crown Caesar king in sea and land outside Italy, as Casca himself relates (1. 3. 85-8). Furthermore, the secret behind the people's high opinion of Brutus is their apprehension of the monarchic ambitions of Caesar. This is why they turn to Brutus as a substitute for Caesar, according to Shakespeare and Plutarch (Dryden 1864, 889).

Therefore, we can elicit that Casca once resorts to prose when he talks about the affairs and activities of the low classes. As far as Shakespeare's metrics of lingual apartheid, resorting to prose is an act of linguistic degeneration, but simultaneously it is a moral and psychological decline. So the ethical deterioration demands a stylistic decline. His words are so lowly and base as he mocks and mimics their vulgar style of utterance. This account condemns him rather than the plebeians. He talks in the same manner and mode of the plebeians whom he snobs. Besides, his language is far below that of the cobbler in meaning, appropriateness, and literary potential.

\subsection{Brutus' oration: a show of educational transcendence}

Another diversion out of traditional norms of language use is Brutus' oration (3. 2. 14-47) addressed to the angry multitudes after the murder of Caesar. It is the only prose speech of Brutus in Julius Caesar. Elsewhere in the play from beginning to end, he speaks in blank verse. This distraction from his regular practice posits a question about the reason why he switches to prose on that occasion. The prominent senator chooses to address the plebeians in a form of utterance appropriate to their understanding. He probably finds blank verse much sophisticated and inappropriate to calm down the disturbed minds of the heated masses.

1. Shakespeare distinguishes the style and form of prose used by Brutus from those of the cobbler and

Casca. The cobbler does not have the sophistication or education available to the patricians and uses prose that is loaded with figurative language that seeks its roots in his everyday vocational jargon. Casca's prose is prejudiced in meaning, crude in style, and there is no method in it, to borrow a phrase from Polonius (Hamlet; 2. 2. 203). Brutus' speech is different; it is very formal, rhythmical, void of images and metaphors, and is structured after the classical theory of rhetoric. This distinction is suitable for the stoic, serious, and virtuous tragic character of the play. Shakespeare's character draws on the historical Brutus, who was trained in rhetoric. Plutarch points out that Brutus "attained a sufficient skill to make public addresses and to plead a cause" (Dryden 1864, 1187). Shakespeare dramatizes him as well trained in Aristotelian Rhetoric (Al-Abdullah 2011). This speech, however, fails at the end to achieve its purpose. Jeffery J. Yu (2007) argues that the speeches of Brutus and Antony seek to persuade the listener. Yu adds that "the ultimate failure of Brutus and the success of Antony are determined by their adherence to Cicero's Sententia" (2007, 98). Nevertheless, an elaborate study by Maram Al-Abdullah (2011) rightly argues that the orations of Brutus and Antony provide rather a perfect implementation of Aristotle's theory of Rhetoric. Besides, we should not forget that the playwright was also literate in Aristotle's treatise on rhetoric that was translated into Latin in the fifteenth-century. To suit his purposes, Shakespeare tailors the speech for Brutus to 
Al-abdullah

implement the major features of the Aristotelian theory (Al-Abdullah 2011, 86-107). And as the purpose of the speech is to placate and persuade the rioting mobs who support Caesar that his death is in their interest and the interest of Rome, Shakespeare formats Brutus' speech after the Aristotelian theory of rhetoric.

2. This study divides Brutus' speech (3. 2. 13-41) into five sections as in Vickers's study (1968, 241-244).

The sections will be analyzed separately before coming to general conclusions. This means to show that Brutus' elitist version of prose is different from Casca's linguistically and morally degenerate one. It also demonstrates that this rigidly elitist excursion from the aristocratic code of speech to persuade the masses fails to fortify the plebeians against the impact of the emotionally wrought oration of Antony in blank verse.

I- Section one: Exordium (the opening section)

Be patient till the last.

Romans, countrymen, and lovers!

a- hear me for my cause, and be silent, that you may hear:

$b$ - believe me for mine honour, and have respect to mine honour, that you may believe:

c-Censure me in your wisdom, and awake your senses, that you may the better judge (italics mine).

These opening statements of Brutus herald the neutrality of his speech, the absence of feelings, and a show of rhetorical devices. The neutrality matches the stoic philosophy of Brutus throughout the play (Boulukos 2004, 1085). The purpose of the speech is to calm down the angry and riotous plebeians by drawing on his budget of honor and respect among them (Al-Abdullah 2011, 91-94) since he "sits high in all the people's hearts" (I. 2. 157). This section has three periods (a), (b), and (c), each having three members. The rhetorical figure epanalepsis of repeating the extreme words hear and believe (Vickers, 1968 ) in periods (a) and (b) provides a sense of rhythmical symmetry. Equilibrium is also secured by the paromoiosis in the repetition of the word honour at the end of the first two members in period (b). Also, musical rhythm is provided by the paronomasia in the words censure and senses in period (c).

II- Section two

This section is composed of the following three periods:

a) If there be any in this assembly, any dear friend of Caesar's, to him I say, that Brutus' love to Caesar was no less than his.

b) If then that friend demand why Brutus rose against Caesar, this is my answer: Not that I loved Caesar less, but that I loved Rome more.

c) Had you rather Caesar were living and die all slaves, than that Caesar were dead, to live all free men? (italics mine)

In this section, the periods (a) and (b) are parallel and symmetrical, thus rhythmical and rhetorical, and as thus persuasive, according to the Aristotelian theory (Al-Abdullah, 2011, 96). According to Vickers $(1968,243)$, the three periods are meant to countermand any possible adversary argument. Brutus here relies on simple antitheses in (a) and (b), mainly in (b) in the statements "...I loved Caesar less" and 


\section{Language and politics: Prose as a Medium of Societal}

Apartheid in Shakespeare's Julius Caesar

"... I loved Rome more." In (c) he multiplies antitheses to serve his inductive reasoning which goes as thus:

[If] Caesar 'were' living, [you would] die all slaves.

[Since] Caesar [is] dead, [you will] live all free men.

In the first member, "Caesar" and "you" are antithetical, and so are "living" and "die." In the second member, "Caesar" and "you" are antithetical, and so are "dead" and "live." Interesting is that the antitheses in the main sentences are reversed in the second member. He multiplies the rhetorical effect by juxtaposing "slaves" and "free men" in the two members. With this argument, the hearers have no other choice but to live as free men, a condition that can be realized only by the death of Caesar.

\section{Section 3:}

This section has eight periods with binary structure:

As Caesar loved me, I weep for him;

as he was fortunate, I rejoice at it;

as he was valiant, I honour him: but

as he was ambitious, I slew him.

The rhetorical rhythm is further multiplied by the use of antimetabole (Vickers 1968, 244), in the latter set of four periods which correspond to the periods above, but in a reversed structure, as follows:

There is tears for his love;

joy for his fortune;

honour for his valour; and

death for his ambition. (3. 2. 51)

In these periods, Brutus forms an enthymeme that is the focal point of his whole speech. The syllogism is structured as thus:

Major premise: Ambitious people are dangerous and should be killed.

Minor premise: Caesar was ambitious.

Conclusion: Caesar was dangerous and had to be killed.

This enthymeme is Brutus' justification for the murder of Caesar, and the whole speech with its recruited devices and tricks of rhetoric is meant to bring this rationalization to the fore.

IV- Section 4:

In this section, Brutus happily fortifies his enthymeme with three highly symmetrical spurious periods of rhetorical questions each followed by a refrain (Al-Abdullah 2011, 99). The orator in this section employs parisosis and tautology. However, the questions rushed after the enthymemes are meant to give the audience no chance to contemplate and apprehend the real reason behind the murder. 
Al-abdullah

Who is here so base that would be a bondman?

If any, speak; for him have I offended.

Who is here so rude that would not be a Roman?

If any, speak; for him have I offended.

Who is here so vile that will not love his country?

If any, speak; for him have I offended. I pause for a reply. (3. 2. 30-35)

Naturally, the listeners are given no chance to be offended since any other option will exclude them from the community of decent Roman citizens.

V- Section 5:

In the last section, Brutus concludes that people are appeased by his virtuosity in prose. They applaud him with the same zest they use to applaud Caesar (Turgut 2015, 49). Brutus concludes with satisfaction:

Then none have I offended. I have done no more to Caesar than you shall do to Brutus. The question of his death is enrolled in the Capitol; his glory not extenuated, wherein he was worthy, nor his offences enforced, for which he suffered death. (3. 2. 36-41)

To maintain his virtuous and decent image in the minds of the commoners, Brutus makes sure to emphasize his friendship and love to Caesar.

However, prose for Brutus is an appropriate form of language to address the mobs. He is proud of his intellectual ability to justify his deeds and persuade his audience in a mode of utterance that enables him to explain the crime in terms that his audience can understand (Gray and Samely 2019, 91). But it ends up to be a show of condescendence and overhead language addressed to the plebeians who are estranged and engaged at the same time, according to Gray and Samely $(2019,91)$. Furthermore, Gray and Samely contend that Brutus' speech is "too calm, too abstract, too aloof, and too self-satisfied" (91). This is why its persuasive effect wears out swiftly after the oration of Antony in blank verse. Different from Shakespeare, Plutarch reports that the plebeians were apathetic to the speech and they were not contented with the justification Brutus gives. Plutarch describes their reaction to his speech, saying that:

Brutus with the rest came down from the capitol and made a speech to the people, who listened without expressing either any pleasure or resentment, but showed by their silence that they pitied Caesar and respected Brutus (Dryden 1864, 893).

Visser questions the mainstream argument that the crowd is fickle and sways by whoever addresses it. If this is the case, he wonders: why does Brutus allow Antony to address it after him (Visser 1994, 24)? What would be the scenario if Antony was the first speaker? Visser argues that both speakers intend to manipulate the commoners. Brutus intends to appease the multitudes (3. 2. 179-80) and Antony has determined to "let slip the dogs of war" (3. 2. 273) prior to his oration. People convert to the argument of Antony, asserts Visser (1994, 24), only because he can refute Brutus' argument. So they behave rationally, not emotionally as many critics would argue. 
Language and politics: Prose as a Medium of Societal

Apartheid in Shakespeare's Julius Caesar

Brutus' speech means to "show [the plebeians] the reason of our Caesar's death" (3.1.237). But instead of delivering a passionate speech to calm down the angry masses and sell them his idea that killing Caesar is in their best interest, he merely exhibits his advanced intellect and training in rhetoric, as if to say that he would not want to win an unfair gain. This orthodox attention to rhetorical devices, figures of speech, and balanced rhythmical and antithetical members render the speech neutral, aloof, and wanting in vividness. Lucking (2010) rightly explains that instead of presenting clear reasons why he and his fellow conspirators have killed "the foremost man of this entire world" (4. 3. 22), Brutus gets captured in a game of rhetoric that "resolves into little more than a dance of empty words" (130).

Moreover, Brutus diverts from his zone of blank verse to prose probably to choose an appropriate form of utterance that is appropriate for the less educated people. Hegel's view that the language of the educated can be viewed at times as "gibberish" applies well in the case of Brutus's speech to the plebeians (Gray and Samely 2019, 92). This is why he is easily "trounced" by Antony (Delaney 2002, 189), whose speech in verse posits an ideal example of juxtaposition between prose and poetry in Shakespeare (Vickers 1968, 244). Vickers calls it a "triumph of verse over prose in the twin orations of Julius Caesar" $(1968,10)$. Antony utilizes all techniques including rhetorical devices and enthymemes to manipulate the mobs. He unweaves the threads of Brutus' argument that Caesar was ambitious and succeeds in refuting it, as we can judge from the early reaction of the plebeians to his speech. It is at that point that Antony launches his assault against the conspirators and stirs a public mutiny that chases the murderers of Caesar out of Rome.

\section{Conclusion}

Prose in Julius Caesar is shown to be a plebeian indigenous form of expression. When they employ it, they win against their aristocratic opponents. The cobbler's witty prose outshines the tribunes' verse utterance in its rhythm, figurative richness, and high literary possibilities. The cobbler's prose also supersedes the verse of the two tribunes in its cognitive and artistic distinction (Boulukos 2004, 1085).

However, when aristocrats in Julius Caesar divert to prose, they either talk about or address the commoners. Their performance in this diversion is either a decline in morality and a slide in style or it can be a total failure in achieving its mission. Casca's use of prose is shown to be a total disappointment. As far as Shakespeare's metrics are concerned in his case, using prose is an act of deterioration in style and degeneration in ethics. His performance in prose is repugnant and vulgar. Furthermore, it indicates decadence in morality and lack of human consideration and understanding. His stepping down to prose is also a decline in decency. Shakespeare juxtaposes his prose in Act 1, Scene 2 with his blank verse in the successive scene. There, he regains his patrician status linguistically and morally. He regains some soberness and his language rises to expectations and sophistication. His use of blank verse is out of the scope of this study, but it deserves further analysis from critics.

The most important prose speech in Julius Caesar is that of Brutus in Act (3. 2). This speech is highly elaborate and ornamented in style and accurately implements Aristotle's theory of rhetoric. He is 
Al-abdullah

given prose to address the plebeians in a language appropriate for their class, which is a requirement of the classical theory of persuasive rhetoric. Yet unlike Casca, Brutus maintains decent morality and virtue in his speech. His style is polished and his use of the game of language is superb. However, Shakespeare shows that the virtuous and educated Brutus directs his attention only to form and ignores the substance and purpose of his oration. His use of prose captivates him and does not give him the freedom to maneuver and gain a final success with the audience. The failure of the speech is measured by the reaction of the plebeians to Antony's oration in blank verse that is immediately rushed after it. Antony's oration posits juxtaposition to Brutus' and succeeds in manipulating and converting the same audience of Brutus to the opposite direction. Antony stirs the plebeians to a massive mutiny that chases Brutus and the conspirators out of Rome, and then to the battlefield where all of them lose their lives.

Shakespeare advocates that prose does not become the upper classes, and when they use it, they decline in style, morality, or both. Shakespeare finds in the Roman political structure an ideal form of class-oriented society, a form that he revives, of course not without modifications, to implement his Elizabethan vision of language forms of utterance as a feature of lingual apartheid and social discrimination.

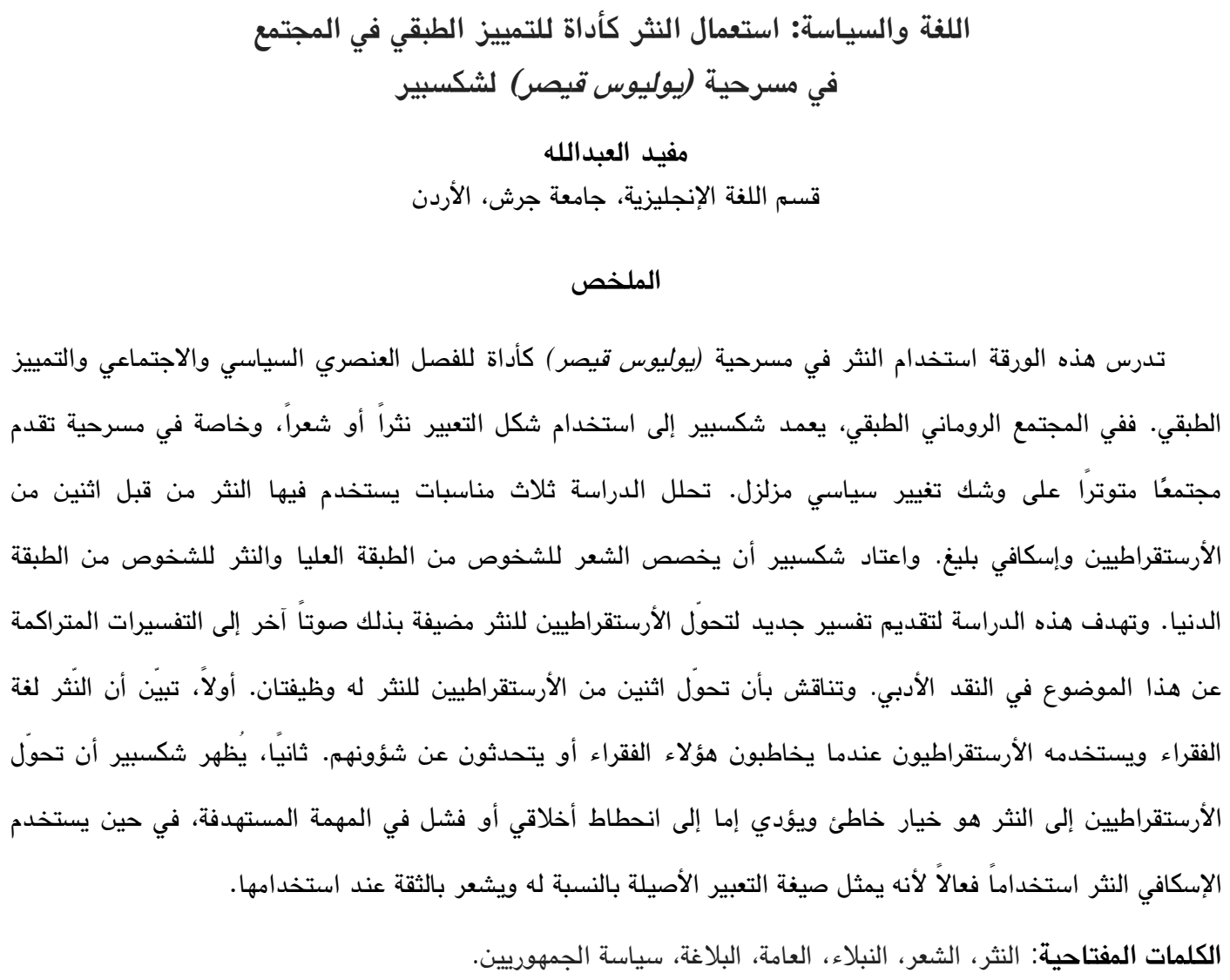


Language and politics: Prose as a Medium of Societal

Apartheid in Shakespeare's Julius Caesar

\section{References}

Al-Abdullah, Maram. 2011. "Aristotle's Rhetorical Strategies in Shakespeare's Julius Caesar". MA thesis, Yarmouk University.

Al-Abdullah, Mufeed F. 2020. The Dialectics of Hostile Dehumanization in Shakespeare's Julius Caesar: A Sociopsychological Approach. Jordan Journal of Modern Languages and Literatures 12 (1): 79-101.

Ballard, Kim. 2016. Prose and Verse in Shakespeare's Plays. https://www.bl.uk/shakespeare/articles/p rose-and-verse-in-shakespeares-plays (accessed Nov. 18, 2019).

Bloom, Allan. 1964. Shakespeare’s Politics. New York: Basic Books.

Boulukos, Athanasios. 2004. The Cobbler and the Tribunes in Julius Caesar. MLN 119: 1083-89.

Bruster, Douglas. 2005. The Politics of Shakespeare's Prose. In Rematerializing Shakespeare, eds., Bryan Reynolds and W.N. West. London: Palgrave Macmillan: 95-114.

Butcher, Samuel Henry. Trans. 2000. The Poetics. Philadelphia: The Pennsylvania State University. http://www2.hn.psu.edu/faculty/jmanis/jimspdf.htm (accessed Oct., 12, 2019).

Clough, Arthur Hugh.1864. Introduction to Dryden's translation of The Lives of the Noble Grecians and Romans, ix-xxiv. New York: Modern Library.

Crane, Milton. 2013. Shakespeare's Prose. Cambridge: Cambridge University Press.

Daniell, David, ed. 1998. Julius Caesar. London: Arden Shakespeare.

Danson, Lawrence. 2004. Julius Caesar. In William Shakespeare, edited by Harold Bloom, 217-30. Broomall: Chelsea House Publishing.

Delaney, Bill. 2002. Shakespeare's Julius Caesar. The Explicator 60 (4): 188-190.

Dryden, John, trans. 1864. The Lives of the Noble Grecians and Romans. New York: Modern Library.

Fitter, Chris, ed. 2018. Shakespeare and the Politics of Commoners: Digesting the New Social History. Oxford: Oxford University Press.

Furness, Horace Howard. ed. 1963. Hamlet. New York: Dover Publications.

Garbero, Maria Del Sapio, ed. 2018. The Illness of Shakespeare's Rome: An Introduction. In Rome in Shakespeare's world, edited by Maria Del Sapio Garbero. Rome: Edizioni Di Storia E letteratura.

Gill, N. S. 2019. Conflicts of the Orders: Patrician and Plebeian. Thoughtco.com/conflict-of-the-orderspatrician-plebeian-120763 (accessed Nov. 20, 2019).

Golden, Leon. 1992. Aristotle on Tragic and Comic Mimesis. London: Scholars Press.

Gray, Patrick, and Maurice Samely. 2019. Shakespeare and Henri Lefebvre's 'right to the city': Subjective Alienation and Mob Violence in Coriolanus, Julius Caesar, and 2 Henry VI. Textual Practice 33 (1): 73-98.

Greene, Gayle. 1980. The Power of Speech / To Stir Men's Blood: The Language of Tragedy in Shakespeare's Julius Caesar. Renaissance Drama 11: 67-93.

Leggatt, Alexander. 1988. Shakespeare's Political Drama. London: Routledge.

Lintott, Andrew William. 1968. Violence in Republican Rome. Oxford: Clarendon. 
Al-abdullah

Lucking, David. 2010. Brutus's Reasons: Julius Caesar and the Mystery of Motive. English Studies 91 (2): 119-132.

Miola, Robert S. 1985. Julius Caesar and the Tyrannicide Debate. Renaissance Quarterly 38: 271-89.

Morgan, Llewelyn. 1997. 'Levi Quidem De Re...' Julius Caesar as Tyrant and Pedant.

The Journal of Roman Studies 87: 23-40.

Murley, John A., and Sutton D Sean. 2006. Perspectives on Politics in Shakespeare. Lanham: Lexington Books.

Parini, Jay. ed. 2005. The Wadsworth Anthology of Poetry. Boston: Cengage Learning: 655.

Patterson, Annabel. 1989. Shakespeare and the Popular Voice. London: Blackwell.

Rollins, Lauren Leigh. 2017. 'Republicans’ Behaving Badly: Anachronism, Monarchy, and the English Imperial Model in Julius Caesar and Antony and Cleopatra. Medieval \& Renaissance Drama in England 30: 165-180

Schulman, Alex. 2014. Rethinking Shakespeare's Political Philosophy: From Lear to Leviathan. Edinburgh: Edinburgh University Press.

Spotswood, Jerald W. 2000. We Are Undone Already: Disarming the Multitude in Julius Caesar and Coriolanus. Texas Studies in Literature and Language 42 (1): 61-78.

Turgut, Fehmi. 2015. Perception Operating in Shakespeare's Julius Caesar. Journal of History, Culture and Art Research 4 (2): 39-55.

Vatter, Miguel. 2012. The Quarrel between Populism and Republicanism: Machiavelli and the Antinomies of Plebeian Politics. Contemporary Political Theory 11 (3): 242-263.

Vickers, Brian. 1968. The Artistry of Shakespeare's Prose. London: Methuen.

Visser, Nicholas. 1994. Plebeian Politics in Julius Caesar. Shakespeare in Southern Africa 7: 22-31.

Wirkner, Linda. 2003. Shakespeare's Julius Caesar. New York: A/V Concept Corp.

Yu, Jeffrey J. 2007. Shakespeare's 'Julius Caesar', Erasmus's 'De Copia', and Sentential Ambiguity. Comparative Drama 41 (1): 79-106. 